\title{
Indication and complication of caesarean section at tertiary care hospital: a retrospective study
}

\author{
Bilal Ur Rehman*, Hiba Gul
}

Department of Obstetrics and Gynecology, Maternity Hospital, SKIMS, Soura, Srinagar, Jammu and Kashmir, India

Received: 14 February 2019

Accepted: 11 March 2019

\section{*Correspondence:}

Dr. Bilal Ur Rehman,

E-mail: drbilalurrehman@gmail.com

Copyright: (c) the author(s), publisher and licensee Medip Academy. This is an open-access article distributed under the terms of the Creative Commons Attribution Non-Commercial License, which permits unrestricted non-commercial use, distribution, and reproduction in any medium, provided the original work is properly cited.

\begin{abstract}
Background: The incidence of cesarean section is steadily rising. Cesarean delivery has played a major role in lowering both maternal and perinatal morbidity and mortality rates. There are various factors involved in the rise of rate of cesarean section like rising incidence of primary cesarean delivery, identification of high-risk pregnancy, wider use of repeat cesarean section, rising rates of induction of labor and failure of induction, no reassuring fetal status etc. Methods: A retrospective cross-sectional study was conducted. Data was collected from patient records of the hospital during $1^{\text {st }}$ January 2018 to $30^{\text {th }}$ June 2018 . All patients $(\mathrm{N}=602)$ who had delivered their baby by caesarean section were included in the study. Data were analyzed by help of SPSS version 21 after proper compilation.

Results: Among all women who underwent cesarean section, majority were age group between 21 and 30 years $(67.1 \%)$. Repeat cesarean section $(48.5 \%)$, followed by fetal distress (18.9\%), oligohydramnias $(6.6 \%)$ and cephalopelvic disproportion (6.5\%) were most common among all major indication of cesarean section. Intrapartum complication $(2.0 \%)$ includes postpartum hemorrhage $(1.2 \%)$, CS hysterectomy $(0.5 \%)$, bladder injury $(0.3 \%)$ and postpartum complication $(2.3 \%)$ including UTI $(0.8)$, wound infection $(0.5 \%)$, sepsis $(0.5 \%)$, lactation failure $(0.5 \%)$ were major maternal complication of cesarean section.

Conclusions: Reduction of number of primary cesarean section, successful VBAC, individualization of the indication and careful evaluation, following standardized guidelines can help to keep rate of cesarean section to the possible minimum level.
\end{abstract}

Keywords: Fetal distress, Malpresentation, Previous cesarean section

\section{INTRODUCTION}

Cesarean section is one of the most commonly performed surgical procedure in appropriateness of increasingly employing a surgical procedure to short circuit or entirely bypass labour and delivery. ${ }^{1}$

According to WHO, though there is no ideal CS rate, CS rate above $10-15 \%$ does not confer additional health benefits in terms of fetal and maternal morbidity and mortility. ${ }^{2}$ According to ICMR study conducted in 30 teaching hospitals in India; there is an increase in CS rate from $21.8 \%$ in $1993-1994$ to $25.4 \%$ in $1998-1999 .{ }^{3}$ The rapid increase in cesarean birth rates from 1996 to 2011 without clear evidence of concomitant decreases in maternal or neonatal morbidity or mortality raises significant concern that cesarean delivery is overused. ${ }^{4}$

The aim of this study is to analyse the indications so as to find out the cause behind the rise in rate of CS and modify them so as to reduce the rate or to keep the rate to the minimum possible level. 


\section{METHODS}

A retrospective cross-sectional study was carried out among 602 patients who underwent cesarean section dating from $1^{\text {st }}$ January 2018 to $30^{\text {th }}$ June 2018 in Department of Obstetrics and Gynecology at tertiary care hospital SKIMS, Soura, Jammu and Kashmir. Data was collected from hospital records.

All patients who delivered their babies by CS during the study period were included in this study. Various variables such as mode of delivery, type of cesarean section, indications and complications of cesarean section were recorded along with demographic data such as age, parity and gestational age.

Data of all the 602 patients was analyzed by using SPSS version 21, Software and Microsoft excel.

\section{RESULTS}

In present study of 602 cases that underwent cesarean section, previous cesarean section was the leading indication to CS [292 (48.5\%)] followed by fetal distress [114(18.9\%)], oligohydramnias [40(6.6\%)], cephalopelvic disproportion [39(6.5\%)], failure to progress [34(5.6\%)], malpresentation [23(3.8\%)], Toxemia of pregnancy [18(3.0\%)], GDM [13(2.2\%) (Table 1).

Table 1: Indication of cesarean section.

\begin{tabular}{|l|l|l|}
\hline Indication & Frequency (n) & Percent \\
\hline Repeat CS & 292 & 48.5 \\
\hline Fetal distress & 114 & 18.9 \\
\hline Failure to progress & 34 & 5.6 \\
\hline Mlpresentation & 23 & 3.8 \\
\hline Toxemia & 18 & 3.0 \\
\hline Placenta previa & 8 & 1.3 \\
\hline Twins & 2 & .3 \\
\hline APH & 9 & 1.5 \\
\hline Post dated & 4 & .7 \\
\hline Prom & 6 & 1.0 \\
\hline CPD & 39 & 6.5 \\
\hline Oligohydroamnios & 40 & 6.6 \\
\hline GDM & 13 & 2.2 \\
\hline Total & 602 & 100.0 \\
\hline
\end{tabular}

As shown in foregoing table, out of previous CS cases, [90 (28.7\%)] patient were having previous cesarean section with oligohydramnias, [36 (11.5\%)] patient were having previous CS with cephalopelvic disproportion. Previous 2 LSCS, previous 3 LSCS, previous 4 LSCS were seen in $[4(1.3 \%)],[33(10.5 \%)],[17(5.4 \%)]$ respectively.

Others are PROM [28 (8.9)], fetal distress [27 (8.6\%)], Toxemia $27(8.6 \%)]$, failure to progress [20 (6.4\%)], malpresentation [17 (5.4\%)], GDM [9.0 (2.9\%)], postdated [6 (1.9\%)] (Table 2).

Table 2: Indication in previous cesarean section.

\begin{tabular}{|l|l|l|}
\hline Indication in previous scar & Frequency (n) & $\%$ \\
\hline Scar with fetal distress & 27 & 8.6 \\
\hline Scar with failure to progress & 20 & 6.4 \\
\hline Scar with malpresentation & 17 & 5.4 \\
\hline Scar with toxemia & 27 & 8.6 \\
\hline Scar with CPD & 36 & 11.5 \\
\hline Scar post dated & 6 & 1.9 \\
\hline Scar with prom & 28 & 8.9 \\
\hline Scar with oligohydroamnios & 90 & 28.7 \\
\hline Scar with GDM & 9 & 2.9 \\
\hline Previous 2 LSCS & 4 & 1.3 \\
\hline Preiousv 3 LSCS & 33 & 10.5 \\
\hline Previous 4 LSCS & 17 & 5.4 \\
\hline Total & 314 & 100.0 \\
\hline
\end{tabular}

Maximum number of CS was in age group of 20-30 years [404(67\%)] followed by >30 years [188(31.1\%)] followed by $<20$ years $[10(1.7 \%)]$ (Table 3 ).

Table 3: Age Group

\begin{tabular}{|l|l|l|}
\hline Age group & Frequency (n) & Percent \\
\hline$<21$ & 10 & 1.7 \\
\hline $21-30$ & 404 & 67.1 \\
\hline$>30$ & 188 & 31.2 \\
\hline Total & 602 & 100.0 \\
\hline
\end{tabular}

Maximum number of CS was in multiparous women [354(58.8\%)] (Table 4).

Table 4: Parity.

\begin{tabular}{|l|l|l|}
\hline Parity & Frequency (n) & Percent \\
\hline Primi & 248 & 41.2 \\
\hline Multi & 354 & 58.8 \\
\hline Total & 602 & 100.0 \\
\hline
\end{tabular}

The tabulated data shows that majority of caesarean section were emergency [383(63.6\%)] (Table 5).

Table 5: Type of cesarean section.

\begin{tabular}{|l|l|l|}
\hline Type of Cesarean & Frequency (n) & Percent \\
\hline Elective & 219 & 36.4 \\
\hline Emergency & 383 & 63.6 \\
\hline Total & 602 & 100.0 \\
\hline
\end{tabular}

[12 $(2.0 \%)]$ patients had intrapartum complications like PPH [7(1.2\%)], CS hysterectomy [3(0.5\%)], bladder injury $[2(0.3 \%)]$ (Table 6) and [14(2.3\%)] patients had postpartum complications like wound infection $[3(0.5 \%)]$, sepsis $[3(0.5 \%)]$, UTI [5(0.8\%)], lactation failure $[3(0.5 \%)]$ (Table 7). 
Table 6: Intra operative complications.

\begin{tabular}{|l|l|l|l|l|}
\hline Intra operative complications & Frequency $(\mathbf{n})$ & $\%$ & Valid percent & Cumulative percent \\
\hline PPH & 7 & 1.2 & 58.3 & 58.3 \\
\hline CS hysterectomy & 3 & 0.5 & 25.0 & 83.3 \\
\hline Bladder injury & 2 & 0.3 & 16.7 & 100.0 \\
\hline Total & 12 & 2.0 & 100.0 & \\
\hline Total & 602 & 100.0 & & \\
\hline
\end{tabular}

Table 7: Postpartum complications.

\begin{tabular}{|l|l|l|l|l|}
\hline Postpartum complications & Frequency $(\mathbf{n})$ & $\%$ & Valid percent & Cumulative percent \\
\hline Wound infection & 3 & 0.5 & 21.4 & 21.4 \\
\hline Sepsis & 3 & 0.5 & 21.4 & 42.9 \\
\hline UTI & 5 & 0.8 & 35.7 & 78.6 \\
\hline lactation failure & 3 & 0.5 & 21.4 & 100.0 \\
\hline Total & 14 & 2.3 & 100.0 & \\
\hline Total & 602 & 100.0 & & \\
\hline
\end{tabular}

\section{DISCUSSION}

Growing rate of CS is a matter of concern everywhere in the world. The present study is a retrospective hospital record-based study, carried out in the department of obstetrics and Gynecology at tertiary teaching institute maternity hospital SKIMS Soura Jammu and Kashmir. In present study the most common indication for caesarean section was repeat caesarean section $(48.5 \%)$ followed by fetal distress (18.9\%) (Figure 1).

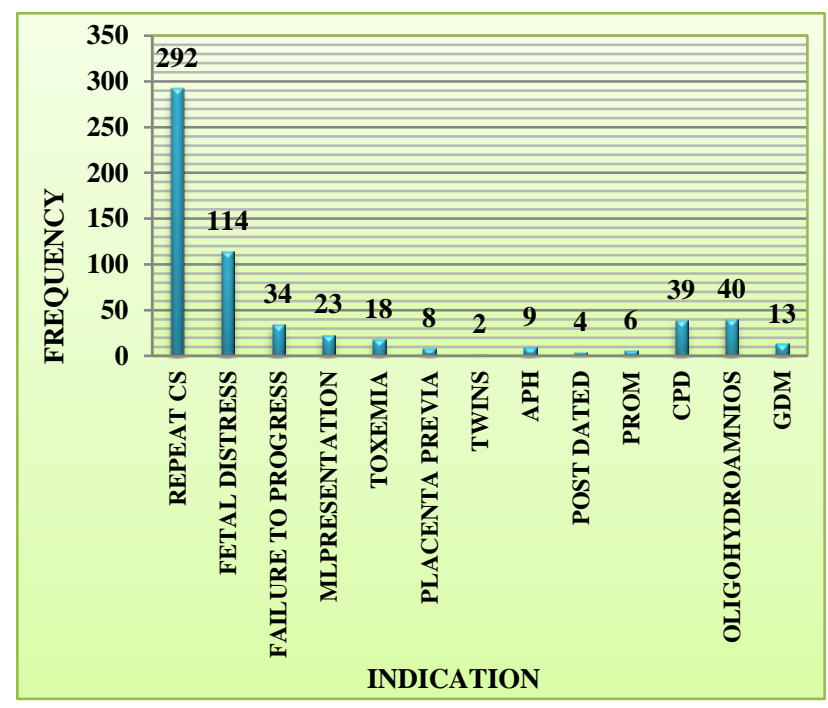

Figure 1: Indication for caesarean section.

Similar results were obtained in study conducted by Pandya JM et al (46.2\%) and (13.4\%) respectively. Previous cesarean section was the commonest indication in a study conducted in developed countries as well. ${ }^{5,6}$ Practice of trial for vaginal birth after cesarean (VBAC) is less in our institute due to doubtful scar strength, details regarding previous CS being not available. No trial was given to patients with previous 2 or more sections and also in those women who refused for vaginal delivery. In present study maximum number of cesarean sections were in age group of 21 to 30 years $67.1 \%$ which is comparable to studies done by Jawa A, et al and Sarma $\mathrm{P}$, et al. ${ }^{7,8}$

Maximum numbers of caesarean section were observed in multiparous women $58.0 \%$ as compared to primiparous $41.2 \%$. Similar results were seen in study done by Dhakal KB et al $53.5 \%$ and $46.5 \%$ respectively. ${ }^{9}$ In present study $63.6 \%$ of cases were operated in emergency for cesarean section, while $36.4 \%$ patients were planned for elective cesarean section. Similar results were found in study done by Pandya JM et al.

The caesarean sections were associated with increased risk of maternal and perinatal morbidity as compared to vaginal deliveries even in low risk cases. ${ }^{5,10}$

In present study, the intra partum complication was PPH $(1.2 \%)$, caesarean section hysterectomy $(0.5 \%)$, bladder injury $(0.3 \%)$ and post-partum complication was UTI $(0.8 \%)$, lactation failure $(0.5 \%)$, wound infection $(0.5 \%)$, sepsis $(0.5 \%)$. In a study by Das RK et al the morbidity rate was found as $12.02 \%{ }^{11}$ Surgical site infection (4.35\%) was the commonest complication followed by atonics PPH (2.43\%).

\section{CONCLUSION}

The main indications of CS were previous CS, fetal distress, oligohydramnias, cephalopelvic disproportion etc.

Maternal complications of CS were low. Reduction of number of primary cesarean section, successful VBAC, individualization of the indication and careful evaluation, 
following standardized guidelines can help to keep rate of cesarean section to the possible minimum level.

\section{ACKNOWLEDGMENTS}

Authors would like to acknowledge the medical records department of present institution for allowing to access the in-patient record files.

\section{Funding: No funding sources}

Conflict of interest: None declared

Ethical approval: The study was approved by the Institutional Ethics Committee

\section{REFERENCES}

1. Wagner M. Choosing caesarean section. Lancet.2000;356(9242):1677-80.

2. Harper V, Hall M. Trends in caesarean section. Current obstet Gynaecol.1991:224-8.

3. Kambo I, Bedi N, Dhillon Bs. A critical appraisal of cesarean section rates at teaching hospitals in India. Int J Gynaecol Obstet. 2002;79(2):151-8.

4. Caughey AB, Cahill AG. Safe prevention of the primary cesarean delivery. Obstetric care consensus.2014;210(3):179-93.

5. Pandya JM, Pandya MJ, Joshi JM, Velani SP. Analytical study of indications of cesarean section. Int J Reprod Contracept Obstet Gynecol 2015;4(5):1460-3.
6. Wang CP, Tan WC, Kanagalingam D, Tan HK. Why we do cesears: a comparison of trends in cesarean section delivery over a decade. Ann Acad Med Singapore. 2013;42(8):408-12.

7. Jawa A, Garge S, Tater A, Sharma U. Indications and rates of lower segment caesarean section at tertiary care hospital-an analytical study. Int J Reprod contracept Obstet Gynecol.2016;5(10):34669.

8. Sarma P, Boro RC, Acharjee PS. An analysis of indications of caesarean sections at Tezpur medical college and hospital, Tezpur (a government hospital). Int J Reprod Contracept Obstet Gynecol.2016;5(5):1364-7.

9. Dhakal KB, Dhakal S, Bhandari S. Profile of caesarean section in mid- western regional hospital in Nepal. J Nepal Health Res Counc 2018;16(38):848.

10. Mylonas I, Friese K. Indications for and risks of elective caesarean section. Dtsch Arztebl Int.2015;112(29-30):489-95.

11. Das RK, Subudhi KT, Mohanty RK. The rate and indication of caesarean section in a tertiary care teaching hospital eastern India. Int J Contemp Pediatr. 2018;5(5):1733-9.

Cite this article as: Rehman BU, Gul H. Indication and complication of caesarean section at tertiary care hospital: a retrospective study. Int J Reprod Contracept Obstet Gynecol 2019;8:1646-9. 